\title{
Twelve Months Down the Line: do we know Anything more about the Presence of the SARS-CoV-2 in Human Semen?
}

\author{
Walter Cardona Maya10 Stefan du Plessis ${ }^{2}{ }^{\circledR}$ \\ ${ }^{1}$ Reproduction Group, Department of Microbiology and Parasitology, \\ Medical School, University of Antioquia, Antioquia, Colombia \\ 2 Department of Basic Sciences, College of Medicine, Mohammed Bin \\ Rashid University of Medicine and Health Sciences, Dubai, United \\ Arab Emirates
}

Rev Bras Ginecol Obstet 2021;43(4):339-340.

Dear Editor,

During the last year, the SARS-CoV-2 infectious agent of COVID-19 has caused more than 75 million infections and 1.5 million deaths worldwide. It has been observed to affect the respiratory tract and exert multiple effects on the human body, including the male reproductive tract. To date, it is understood that although the general infection rate is similar in men and women (50\%), deaths in the male population are higher. ${ }^{1}$ It has even been reported that the prostate expresses the virus receptor, which could negatively affect the seminal quality and could have a severe effect on human reproduction. ${ }^{2,3}$ Therefore, this commentarýs objective was to analyze the scientific data published to date on the presence of the virus in semen.

A literature search of the PubMed and Google Scholar databases was performed using the following keywords:
Address for correspondence Walter Cardona Maya, Cl. 67 \#\#53-108, Medellín, Antioquia, Colômbia

(e-mail: wdario.cardona@udea.edu.co).

COVID-19, SARS-CoV-2, seminal, semen, and sperm. To date, only fourteen articles (both originals and case report $)^{4-17}$ described on the presence of the virus in semen samples. Of these, only a single study described to have identified the virus to be present in six semen samples from SARS-CoV-2 positive patients. ${ }^{4}$ None of the remaining 13 studies detected the virus in the semen of 351 COVID-19 positive men (-Fig. $\mathbf{1}$ ).

Based on current evidence, although the virus could be causing adverse effects in the male reproductive tract, its presence in semen continues to be debated because current evidence suggests that the probability of being in semen is very low (1.68\%). Consequently, the likelihood of infection through sexual intercourse would be extremely weak. Therefore, as a matter of urgency, further studies on this matter should be pursued. received

February 14, 2021

accepted

March 16, 2021
DOI https://doi.org/

10.1055/s-0041-1729948. ISSN $0100-7203$. (c) 2021. Federação Brasileira de Ginecologia e Obstetrícia. All rights reserved.

This is an open access article published by Thieme under the terms of the Creative Commons Attribution License, permitting unrestricted use, distribution, and reproduction so long as the original work is properly cited. (https://creativecommons.org/licenses/by/4.0/)

Thieme Revinter Publicações Ltda., Rua do Matoso 170, Rio de Janeiro, RJ, CEP 20270-135, Brazil 


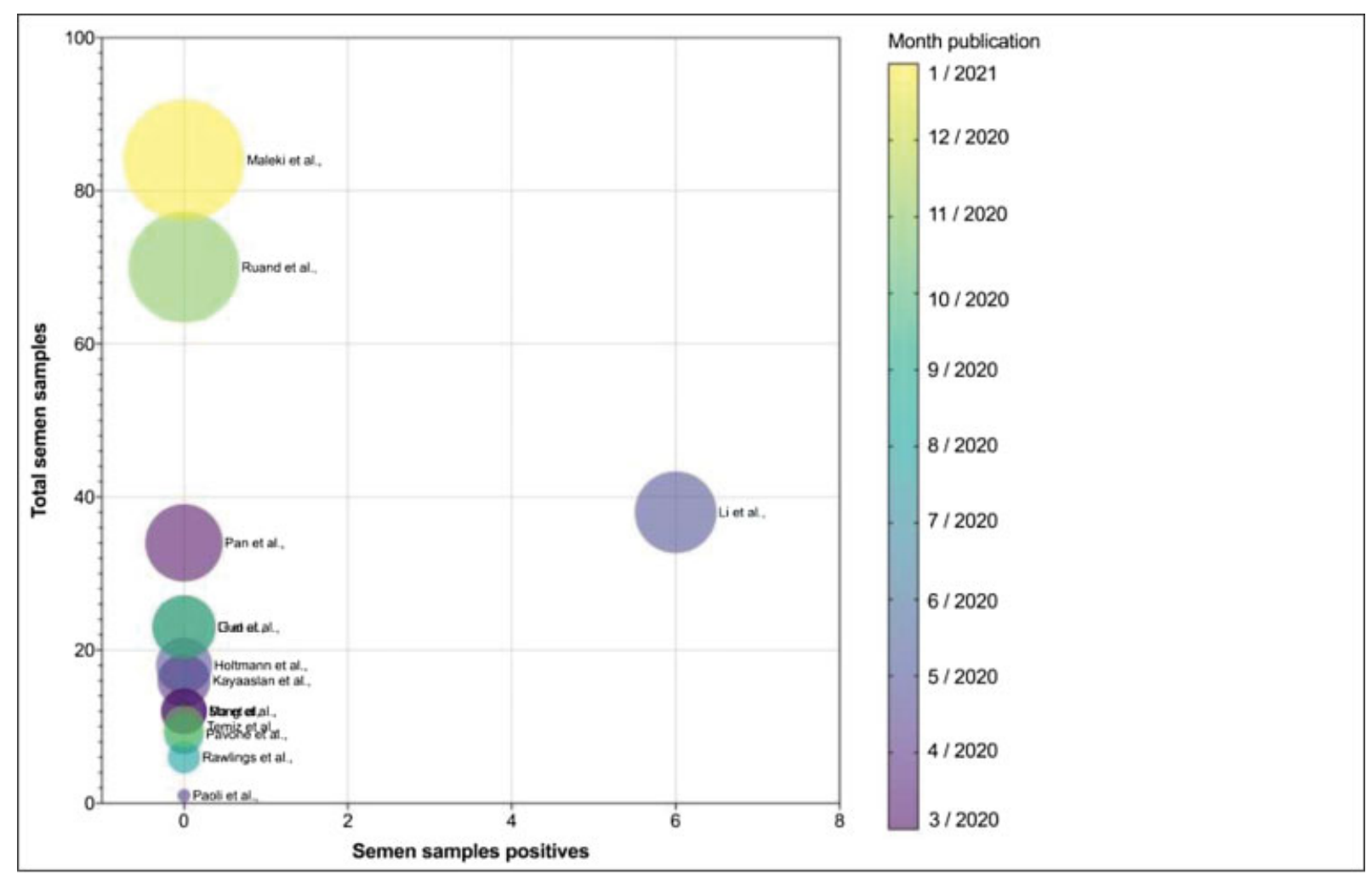

Fig. 1 SARS-CoV-2 in semen samples. Total semen samples (the size of each bubble is proportional), positive samples, and date publication (color).

\section{Conflicts to Interest}

None to declare.

\section{References}

1 Montaño Mendoza VM, Mendez Cortina YA, Velilla Hernandez PA, Cardona Maya WD. Understanding SARS-CoV-2 infection in males. J Med Res. 2020;6(05):180-182. Doi: 10.31254/jmr.2020.6502

2 Cardona Maya WD, Du Plessis SS, Velilla PA. SARS-CoV-2 and the testis: similarity with other viruses and routes of infection. Reprod Biomed Online. 2020;40(06):763-764. Doi: 10.1016/j.rbmo.2020.04.009

3 Omolaoye TS, Adeniji AA, Cardona Maya WD, du Plessis SS. SARSCOV-2 (Covid-19) and male fertility: Where are we? Reprod Toxicol. 2021;99:65-70. Doi: 10.1016/j.reprotox.2020.11.012

4 Li D, Jin M, Bao P, Zhao W, Zhang S. Clinical characteristics and results of semen tests among men with coronavirus disease 2019. JAMA Netw Open. 2020;3(05):e208292. Doi: 10.1001/jamanetworkopen.2020.8292

5 Kayaaslan B, Korukluoglu G, Hasanoglu I, Kalem AK, Eser F, Akinci $\mathrm{E}$, et al. Investigation of SARS-CoV-2 in semen of patients in the acute stage of COVID-19 infection. Urol Int. 2020;104(910):678-683. Doi: 10.1159/000510531

6 Holtmann N, Philippos E, Marcel A, Doehmen C, Baston-Buest D, Adams O, et al. Assessment of SARS-CoV-2 in human semen-a cohort study. Fertil Steril. 2020;114(02):233-238. Doi: 10.1016/j. fertnstert.2020.05.028

7 Song C, Wang Y, Li W, Hu B, Chen G, Xia P, et al. Absence of 2019 novel coronavirus in semen and testes of COVID-19 patients. Biol Reprod. 2020;103(01):4-6. Doi: 10.1093/biolre/ioaa050

8 Guo L, Zhao S, Li W, Wang Y, Li L, Jiang S, et al. Absence of SARSCoV-2 in semen of a COVID-19 patient cohort. Andrology. 2021;9 (01):42-47. Doi: 10.1111/andr.12848

9 Pan F, Xiao X, Guo J, Song Y, Li H, Patel DP, et al. No evidence of severe acute respiratory syndrome-coronavirus 2 in semen of males recovering from coronavirus disease 2019. Fertil Steril. 2020;113(06):1135-1139. Doi: 10.1016/j.fertnstert.2020.04.024

10 Rawlings SA, Ignacio C, Porrachia M, Du P, Smith DM, Chaillon A. No evidence of SARS-CoV-2 seminal shedding despite SARS-CoV2 persistence in the upper respiratory tract. Open Forum Infect Dis. 2020;7(08):a325

11 Ma L, Xie W, Li D, Shi L, Ye G, Mao Y, et al. Evaluation of sex-related hormones and semen characteristics in reproductive-aged male COVID-19 patients. J Med Virol. 2021;93(01):456-462. Doi: 10.1002/jmv.26259

12 Li H, Xiao X, Zhang J, Zafar MI, Wu C, Long Y, et al. Impaired spermatogenesis in COVID-19 patients. EClinicalMedicine. 2020; 28:100604. Doi: 10.1016/j.eclinm.2020.100604

13 Pavone C, Giammanco GM, Baiamonte D, Pinelli M, Bonura C, Montalbano M, et al. Italian males recovering from mild COVID-19 show no evidence of SARS-CoV-2 in semen despite prolonged nasopharyngeal swab positivity. Int J Impot Res. 2020;32(05): 560-562. Doi: 10.1038/s41443-020-00344-0

14 Ruan Y, Hu B, Liu Z, Liu K, Jiang H, Li H, et al. No detection of SARS-CoV2 from urine, expressed prostatic secretions, and semen in 74 recovered COVID-19 male patients: A perspective and urogenital evaluation. Andrology. 2021;9(01):99-106. Doi: 10.1111/andr.12939

15 Temiz MZ, Dincer MM, Hacibey I, Yazar RO, Celik C, Kucuk SH, et al. Investigation of SARS-CoV-2 in semen samples and the effects of COVID-19 on male sexual health by using semen analysis and serum male hormone profile: A cross-sectional, pilot study. Andrologia. 2021;53(02):e13912. Doi: 10.1111/and.13912

16 Hajizadeh Maleki B, Tartibian B. COVID-19 and male reproductive function: a prospective, longitudinal cohort study. Reproduction. 2021;161(03):319-331. Doi: 10.1530/rep-20-0382

17 Paoli D, Pallotti F, Colangelo S, Basilico F, Mazzuti L, Turriziani O, et al. Study of SARS-CoV-2 in semen and urine samples of a volunteer with positive naso-pharyngeal swab. J Endocrinol Invest. 2020;43 (12):1819-1822. Doi: 10.1007/s40618-020-01261-1 